\title{
ON THE SO-CALLED BOTTLE-BACILLUS (DERMATOPHYTON MALASSEZ).
}

BY HERMANN DOLD, M.D.

(With Plate XXI.)

THE organism, commonly known under the name of the Bottlebacillus (Flaschen-bacillus; Bacille-bouteille), was first described by Malassez (1874, pp. 203 et seq.), whose observations led him to the following conclusions (p. 211): "Il existe dans la pelade un champignon parasite. Ce champignon occupe les parties les plus superficielles de la couche cornée de l'épiderme; on le trouve entre ou à la surface des cellules épithéliales de cette couche. Il ne se rencontre qu'accidentellement sur les cheveux, et encore siége-t-il sur des cellules épithéliales, qui proviennent de l'épiderme cutané. Il est uniquement constitué par des spores sphériques très-petites. On peut en distinguer trois types :

“(1) Les premières mesurent de $4 \mu$ à $5 \mu$, ont un double contour, peuvent avoir des bourgeons; ce sont les grosses spores.

“(2) Les seconds mesurent de $2 \mu$ à $2,5 \mu$, n'ont pas de double contour, peuvent avoir des bourgeons ; ce sont les petites spores.

“(3) Les troisièmes ont un diamètre inférieur à $2 \mu$, un contour simple, pas des bourgeons; ce sont les sporules.

“Les spores ovoides que l'on peut encore rencontrer ne sont pas spéciales à la pelade et paraissent appartenir à une autre espèce de champignon.

"Il n'existe pas de tubes, mais seulement des petits chaplets, de $5 \mu$ à $6 \mu$ spores et plus. Ces résultats confirment la découverte de $\mathbf{M}$. Gruby (i.e. Microsporon audouini), dans ce qu'elle a d'essentiel; mais ils en diffèrent complètement sur quelques points de détail."

Thus it is evident that Malassez had before him the same organism which was subsequently described by Unna (1894), and called "Flaschenbacillus" ( = Bottle-bacillus), because of the bottle- or flask-shaped form which it shows under natural conditions on the skin. This is the name 
by which the organism is commonly known. It will also be noted that Malassez distinguishes three types of the organism, a distinction which is based on the size of the "spores"; further that he believes that the ovoid forms which he also observed have nothing to do with the "champignon de la pelade" but belong to a special kind of parasite. He also thought it necessary to discuss the question of the identity or not of his "champignon de la pelade" with the parasite previously detected by Gruby (1843), the "Microsporon audouini."

In another paper Malassez (1874 (a), p. 451) describes the parasite found in Pityriasis, which, although having a great resemblance to the "champignon de la pelade," differs therefrom, in his opinion, in some points, for he states (p. 463) that "Ils se distinguent de celles de la pelade en ce que ces dernières sont habituellement sphériques et plus volumineuses; de celles des autres champignons connus en ce que ces dernières possèdent des tubes de mycélium."

Although the organism has been more fully described by Unna (1894), and by Sabouraud $(1897,1902)$, there is, as yet, no unanimity as to the part it plays in pathology. Its discoverer, Malassez (1874 (a), p. 463), was inclined to see in the "champignon de la pityriasis simple" the cause of the condition: "Ils paraissent jouer dans la pathogénie du pityriasis le même rôle que les autres parasites dans celles des affections cutanées généralement considerées comme de nature parasitaire."

I cannot find a definite statement in Unna's papers of his view regarding the part played by this organism, but it seems to me, that he considers it to be a mere saprophytic inhabitant of the skin. Sabouraud, on the other hand, has apparently changed his former view on the "Bacille-bouteille." In his first paper (1897) he says, "On peut rencontrer accidentellement une dizaine d'espèces microbiennes différentes, parmi lesquelles deux sont constantes. Ce sont le Bacillebouteille de Unna,......et qui parât n'avoir aucune valeur pathogène." In his second publication, when speaking about the relationship between the Bottle-bacillus and Pityriasis, he says, "Et sa présence aux points mêmes où l'on voit les couches épidermiques se cliver, semble affirmer son rôle causal dans le clivage même et l'exfoliation de l'épiderme."

Whitfield (1907) also seems inclined to ascribe a pathogenic rôle to the bottle-bacillus, in Pityriasis: "No one can work at the distribution of Pityriasis alba, and the Bottle-bacillus, without being struck by their invariable association," whereas Malcolm Morris (1908) considers that " the rôle played by the Bottle-bacillus requires further elucidation." 
Frequent trials have been made to obtain this organism in pure culture, but apparently without success. Possibly both Unna ${ }^{1}$ and Whitfield ${ }^{2}$ had at one time, without realising the fact, a pure culture of the organism, but it is of course impossible now to be certain about it.

As I announced in my preliminary note (1909), I have succeeded in obtaining pure cultures of the bottle-bacillus. Since the appearance of my publication, I have made a study of the morphological and biological characters of this organism, which, for reasons given in the course of this paper, I shall henceforth refer to as Dermatophyton Malassez (or "D. M." for brevity).

\section{Occurrence of the Dermatophyton Malassez.}

As shown by Unna, this organism is found in many conditions of the skin. It is present in larger or smaller numbers, alone or associated with other bacteria, in Rosacea seborrhoica, Pityriasis capitis, Alopecia pityroides, Alopecia seborrhoica, Alopecia excematosa, Pityriasis rubra seborrhoica, and in Comedones. The organism is also almost invariably found in apparently healthy persons, in horny cells and the sebum of the skin, especially of the scalp.

There is certainly a great variation in the number of $D$. M. to be met with on individual skins. The more a skin inclines to a seborrhoic and pityroid state, the more abundantly are the organisms present, but in examining a large number of scalps, I did not come across one case, where the presence of $D$. M. could not be demonstrated. I might mention here, that in animals (Rats and Rabbits), I did not encounter the organism; my examinations in this direction are however too few to justify a definite statement.

\section{Methods.}

In examining for the D. M. it is perhaps best to use scrapings from the scalp. These may easily be obtained, by drawing the edge of a slide over the scalp, at the same time pressing the slide firmly against

1 Unna (1894), pp. 233 and 234, says "An abgekratzten Hornzellen habe ich microscopisch öfters grössere Mengen der Flaschenbacillen constatiert, doch die Culturen ergaben gleichzeitig Morokokken."

2 Whitfield (1907, p. 76) states that "The organism has not been grown in pure culture, but on one occasion I succeeded in getting an impure culture, which however rapidly died out." 
the skin. The material thus obtained is smeared on the slide. The smear is fixed by passing it through a flame, after which it is further fixed, and freed from grease, by immersing the slide, in equal parts of alcohol and ether, for 5 minutes. The smear may now be stained with any aniline dye. In stained specimens the D. M. is found as larger or smaller spheroid or ovoid bodies, which very often show a protrusion or budding at one end, like yeast cells. These bodies represent flaskor bottle-like forms (see Plate XXI, fig. 1). Here and there are found bacillary forms of varying length and thickness, filaments, and short chains of the above-mentioned round bodies.

\section{The Cultures.}

For the cultivation of this organism the material obtained in the way above described is ground up and emulsified in 0.5 to 1.0 c.c. of sterile normal saline solution or broth, and then plated out on ordinary nutrient agar, or, preferably, on acid agar. The plates are then incubated at $37^{\circ} \mathrm{C}$. The colonies of $\mathrm{D}$. M. become visible to the naked eye in 24 hours as delicate round discs, dull white by reflected light, pearl-grey by transmitted light. If examined with a low power, the colony appears finely granular, the margin being slightly serrated. As the colony grows older, the margin becomes more and more irregular. Stained preparations of such a colony show large coccus-like forms, partly arranged in short chains, partly in clusters, so that at the first glance they might be taken for Staphylococci (see Plate XXI, fig. 2). A more careful observation shows, however, some differences. First of all the forms are, as a whole, somewhat large for Staphylococci; here and there a much smaller cell adheres to a larger one, like a daughter to a mother cell. Intermixed with these coccus forms, there are ovoid and short bacillary forms, the latter being rarely encountered. Viewed in a hanging drop preparation, the organisms are not motile; they contain granules, vacuoles, and many have a more polyhedric than exactly round form.

If the same organism be subcultured on an acid medium, for example Sabouraud's, recommended for the cultivation of Bacillus acnes (agar 15 grms.; peptone 20 grms.; glycerine 20 grms. ; distilled water 1 litre; glac. acetic acid 5 drops) the growth is far more abundant. A stained preparation shows very irregular, but as a whole much larger forms than those grown on ordinary agar. The organisms appear as large round bodies, some swollen and faintly stained (involution forms?), others as 
large ovoid and bacillary forms, some budding, some showing irregular swellings along their course, others again being club-shaped (see Plate $\mathrm{XXI}$, fig. 3).

On other solid media, such as ordinary serum, they grow in much the same way as on agar. They do not change the colour of neutralred agar, and form a light red shining film on the top of the stab culture. On potato at $22^{\circ} \mathrm{C}$. the organisms form within two to three days a moist shining yellowish film, which spreads slowly. Potato cultures at $37^{\circ} \mathrm{C}$. scarcely show any growth.

The growth of this organism in gelatin stab cultures is most characteristic. Two or three days after inoculation the organisms grow in a fine line along the track of the needle, and form a delicate bluish or yellowish white film on the top. After from one to two weeks, a short radiating outgrowth appears along the track of the needle, whereas the growth on the top represents a sort of "corona radiata," with a central shallow pit. The organisms continue to grow slowly in this regularly radiating manner on the top, and, after 3 or 4 weeks, the single "radii," starting from the periphery, split up into separate segments or leaflets, so that the appearance of a "Daisy-Head" results (see Plate XXI, fig. 5). The separate leaflets soon cease to grow with the same regularity as hitherto and in cultures two to four months old, the growth on the surface of the gelatin is somewhat fernlike.

In broth, the D. M. develops still more peculiar and irregular forms than on acid media, the most remarkable feature being the development of long filaments and threads; besides there are large spheroid and ovoid forms, with or without budding, and chains of large round bodies. Sometimes a sort of false branching of the filaments can be seen, but I also observed instances of true branching (see Plate XXI, fig. 4). The broth shows in 24-28 hours after inoculation a general turbidity, but later on clears up, a deposit being formed at the bottom. If the organisms be again subcultured on ordinary solid media (agar, serum, etc.) the coccoid forms reappear (as in Plate XXI, fig. 2).

The same growth as in broth occurs in other liquid media, peptone water, milk, etc.

Milk remains unchanged. Indol is not formed.

The organisms grow aerobically and anaerobically, either at $22^{\circ} \mathrm{C}$. or $37^{\circ} \mathrm{C}$. 


\section{Staining reactions.}

The organisms are not acid-fast. When stained according to Gram's method, they are as a rule found to be Gram-positive; the larger forms of the organism (bacilli, filaments) are however often decolourised.

\section{Fermentation reactions.}

As the morphological characters of the D. M. seemed to suggest a yeast-like nature, I thought it worth while to test its effect upon a series of sugars, and upon starch. The results of these experiments are given in the following table.

Observations made three weeks after inoculation.

$\begin{array}{lccc}\text { Sugars } & \text { Acid } & \text { Gas } & \text { Remarks } \\ \text { Glucose } & + & + & - \\ \text { Lactose } & (+) & - & \text { Only traces of acid. } \\ \text { Galactose } & - & - & - \\ \text { Levulose } & (+) & - & \text { Only traces of acid. } \\ \text { Maltose } & (+) & - & \text { Only traces of acid. } \\ \text { Raffinose } & - & - & - \\ \text { Cane-sugar } & - & - & - \\ \text { Dulcite } & - & - & - \\ \text { Mannite } & - & - & - \\ \text { Inuline } & - & - & - \\ \text { Starch } & (+) & - & \text { Only traces of aeid. }\end{array}$

A glance at the above table shows that the D. M. has not great fermentative power, glucose being the only sugar that shows a distinct though rather slow fermentation, the production of acid not being recognizable until the second or third day. The amount of acid and gas formed in a three weeks' culture in glucose broth is inconsiderable.

\section{Pathogenicity.}

I experimented on eight animals, two rats, two guinea-pigs, and four rabbits. The two rats were shaved on the back, over an area of about two inches in diameter, any injury of the skin being carefully avoided. Material from a two days' broth culture was then rubbed into the clean 
shaven skin. No pathogenic effect followed. The shaven part of the skin again became covered with hair. The skin and hair both remained normal.

The two guinea-pigs were each inoculated intraperitoneally with 0.5 c.c. of a two days' broth culture. The animals showed a transitory indisposition, but soon recovered, and remained healthy for four months (present date).

Two rabbits were injected subcutaneously in the back, with 0.5 c.c. and 1.0 c.c. respectively, of a three days' culture of the organism. No suppuration resulted. The organisms were evidently destroyed and absorbed. The animals remained healthy for four months (present date).

Two other rabbits received respectively 0.5 and 1.0 c.c. of a three days' broth culture injected into the ear-vein. After a period of uneasiness, lasting one to two days, the animals recovered and seemed healthy. They were killed three months after the inoculation. The organs were normal, excepting one suprarenal gland; this was enlarged, and was found on microscopic sections to contain suppurating foci, in which numerous D. M. (spheroid, ovoid, bacillary and bottle forms) were present.

From these experiments it is evident that the D. M. is not pathogenic for rats and guinea-pigs. The slight effect observed in one rabbit, after the intravenous injection of a large dose of culture, is curious, but cannot be accepted as sufficient evidence that the organism is really pathogenic. The experiments on animals do not of course exclude its being pathogenic to man, though this appears rather unlikely; I regret that I had no opportunity of testing this experimentally.

Malassez distinguishes three types of this organism, the distinction being based on the size of the individual cells. Having shown the extraordinary polymorphism, of which D. M. is capable, I think that this distinction is not justified. The same is true of his distinction between the "champignon de la pelade" and the "champignon de la pityriasis simple" and of his assumption that the ovoid forms to be met with belong to another species. The mere morphological differences, which led Malassez to regard these forms as distinct, also appear to me to be insufficient. It is possible that the organisms found in Pityriasis differ biologically from those found on healthy or seborrhoic skins (like those from which I obtained my cultures), but it is most improbable. 


\section{ConClusions.}

It appears, therefore, that the organism described in this paper is a harmless permanent inhabitant of the superficial layer of the human skin, and that its presence in larger or smaller number depends on the more or less favourable conditions existing in different skins. Diseased skins, especially seborrhoic and pityroid, offer evidently the best conditions for the existence and multiplication of this organism.

The greasy state of the skin in Seborrhoea, the larger amount of horny cells thrown off in Pityriasis, the increased disintegration on the surface of the skin, together with an increased formation of fatty acids, may be regarded as conditions which favour the growth of this saprophyte. I would revert here to the fact that the organism showed a far more abundant growth in acid than in alkaline or neutral media.

Taking into consideration the cultural results obtained, I believe (contrary to my opinion expressed in my preliminary note) that the organism should rather be placed between the Hyphomyceta and Blastomyceta, than classified with the latter.

It appears to belong to the genus Oidium, together with the other well-known parasites of the skin.

The name "Bottle-bacillus," though very well expressing a morphological characteristic of this organism, is inadequate, if one considers its position in the system of bacteria. Malassez, when he first described this organism, called it a "champignon," and thought it closely related to the Microsporon audouini of Gruby. My experiments seem to corroborate Malassez's original view, in so far as they indicate that this organism, though evidently a rather harmless saprophyte of the skin, and of the skin only, belongs to the same group as the pathogenic parasite of skin and hairs (Trichophyta); I therefore venture to propose for this organism the name Dermatophyton Malassez.

\section{REFERENCES.}

DoLd, H. (1909). The cultivation of the so-called Bottle-bacillus. Journ. Royal Inst. of Public Health, No. 12, 748.

Gruby (1843). Recherches sur la nature, le siège et le développement du Porrigo decalvans ou Phyto-alopécie. Compt. rend. Acad. $S c$., xvII. 301 et seq.

Malassez, L. (1874). Note sur le champignon de la pelade. Arch. de Physiol., II. Ser., T. 203 et seq. 


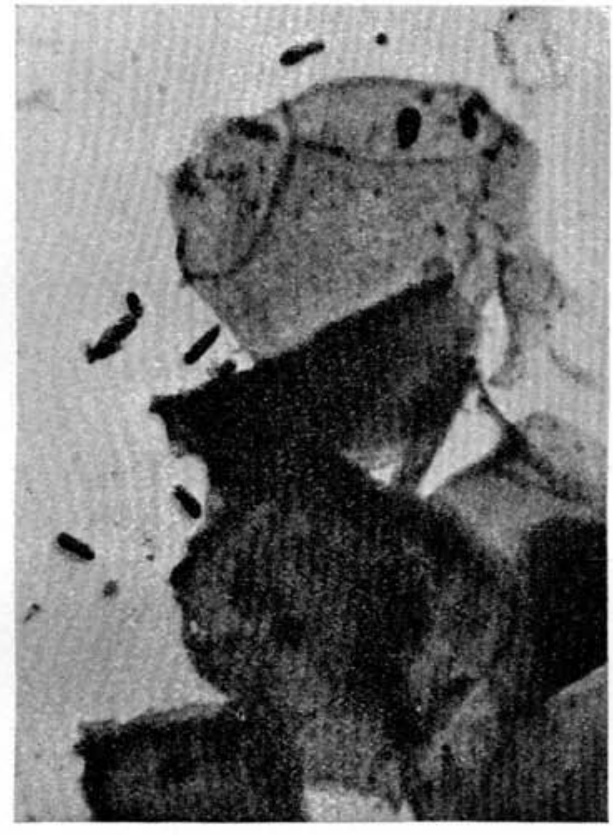

Fig. I.

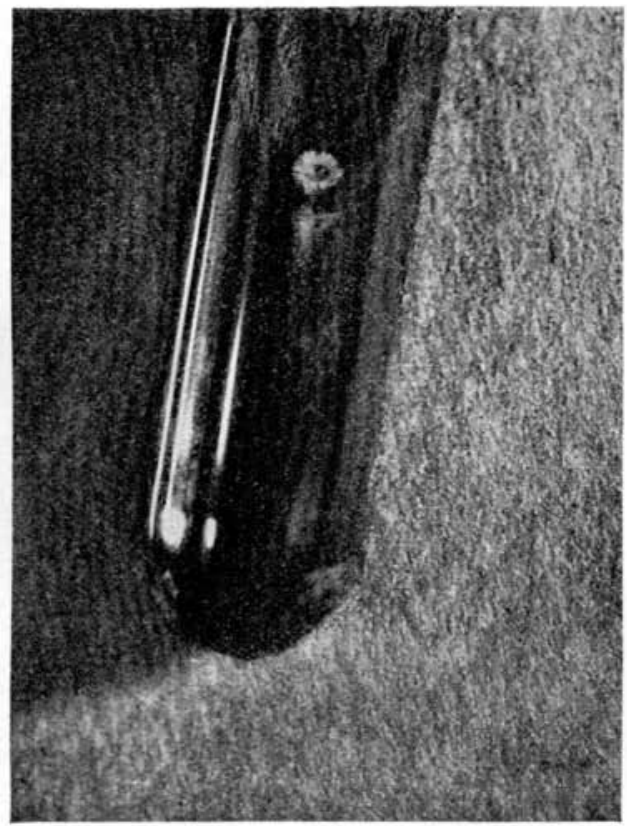

Fig. 5.

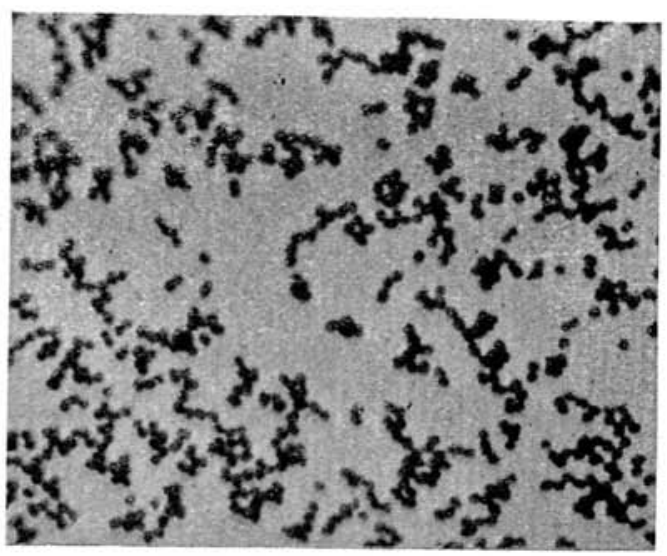

Fig. 2.

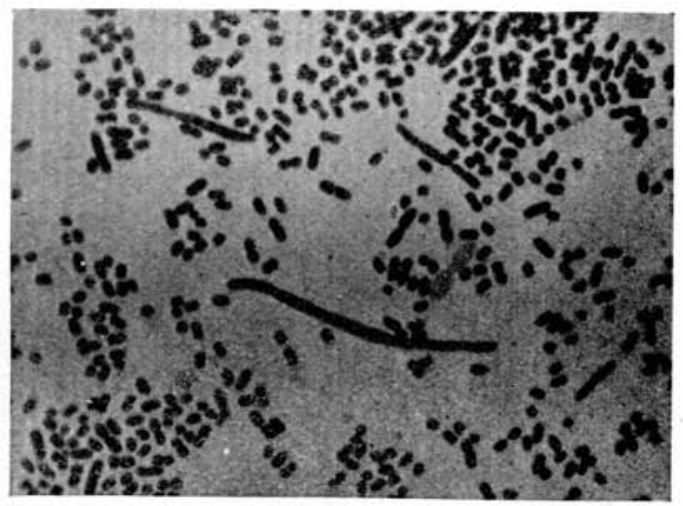

Fig. 3 .

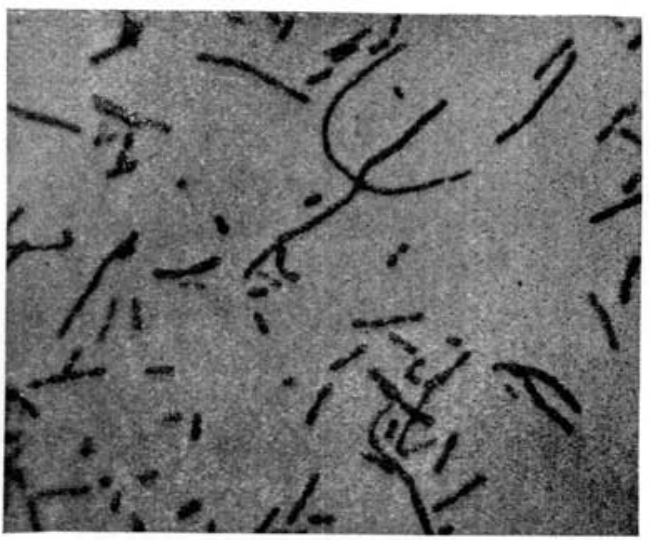

Fig. 4. 

Malassez, L. (1874 a). Note sur le champignon du Pityriasis simple. Arch. de Physiol. Ir. Ser., r. 451 et seq.

Morris, Malcolm (1908). Diseases of the Skin, pp. 15, 19.

Sabouraud, R. (1897). La seborrhée grasse et la pelade. Ann. Inst. Pasteur, xi. 134 et seq.

(1902). Seborrhée, Acnes Calvitie. Paris, p. 107.

UnNa (1894). Die Histopathologie der Hautkrankheiten. Ergänzungs-band zum Lehrb. der Path. Anut. von Dr J. Orth, pp. 234, 236, 239, 244, 246, 249, 352, $1108,1109$.

WhITFIELD (1907). Skin diseases and their treatment, p. 76.

\section{EXPLANATION OF PLATE XXI.}

The photo-micrographs were all taken with Leitz oil immersion objective $\frac{1}{12}$, and ocular 4 . Stained with Fuchsin.

Fig. 1. Scrapings of seborrhoic scalp, showing scratched-off horny cells, and Dermatophyton Malassez (large round cells, bacillary and bottle forms). $\times 1200$.

Fig. 2. Two days' culture of D. Malassez on ordinary agar, showing coccoid forms. $\times 1200$.

Fig. 3. Two days' culture of D. Malassez on acid agar (Sabouraud's medium), subcultured from an ordinary culture on agar (Fig. 2) showing large, round, ovoid forms, bacilli, and filaments with spindle-like swellings. Near the centre two large ovoid forms, faintly stained. $\times 1200$.

Fig. 4. Two days' culture of D. Malassez, in ordinary broth, subeultured from ordinary agar culture (Fig. 2), showing large round and ovoid forms, bacilli, "bottles," and filaments. $\times 1200$.

Fig. 5. Four weeks' gelatin stab culture of $D$. Malassez showing the radiating outgrowth along the needle track, and the "Daisy-head" on the top. $\times 1 \frac{1}{2}$. 